\title{
Ferdinandy, György. 2016. Fekete karácsony ('Black Christmas'). Budapest: Fókusz Egyesület/Magyar Napló Kiadó. 203 pp. Photos.
}

\author{
Reviewed by Mario D. Fenyo*, Bowie State University
}

At the risk of being misunderstood, I should reveal that it took me at least one month to read György Ferdinandy's fictionalized or novelized recollections of his experiences of the 1956 Hungarian Uprising, assembled in his recent volume entitled Fekete karácsony ['Black Christmas']. I do not mean that the book is "slow reading" because it is dull. Nor do I mean that the language is so abstruse that the reader, even a native speaker of Hungarian like myself, might have some difficulties in deciphering the literal meaning of some of its words and phrases, although that may, indeed, be part of the reason for the slow pace of my reading. Rather, I mean that reading Ferdinandy's book takes a mental effort and considerable imagination on the part of someone who was not around in Hungary during the fateful days of the Hungarian Uprising of 1956. It took me a whole month - that is, until the time I reached the end of the volume - to finally realize that the author must have meant these recollections to be taken as authentic, or as nearly authentic (for my similar dilemma while reading another recent book by Ferdinandy, see: https://ahea.pitt.edu/ojs/index.php/ahea/article/view/150).

In more concrete terms, Ferdinandy's most recent book is a series of sketches, assembled in a more or less chronological order, about his personal experiences and encounters relating to the uprising of 1956, including events leading up to it or ensuing from it. The point of view is that of one Yuri, which is, curiously enough, a Russianized version of the author's Hungarian name, Gyuri or György. While I find it difficult to define the nature of the book I figured out what it is not: it is clearly not a journal, nor journalism, nor a memoir, nor even an eye-witness account. Hence the reader is justified in entertaining some degree of skepticism regarding the reality of depicted events. This "reality," however, is undergirded by a set of photographs of the author, reproduced in the volume: these were taken around 1956, near an unidentified "River."

The volume received support from the memorial committee to commemorate the sixtieth anniversary of the "revolution and freedom fight" of 1956. Indeed, was it a revolution, a freedom fight, an uprising, or what? Just to raise such questions has already alienated half the potential, presumably Hungarian, readers! The collection has no heroes, nor even anti-heroes, but it is sufficiently mystifying to prompt the reader to investigate, to seek facts, to look for historical events, to find some dispassionate account. I should add, by way of clarification, that I am a

*mfenyo@bowiestate.edu

$($ (c) $)$ EY

ULIS D-Sente
New articles in this journal are licensed under a Creative Commons Attribution 4.0 International License.

This journal is published by the University Library System of the University of Pittsburgh as part of its D-Scribe Digital Publishing Program and is cosponsored by the University of Pittsburgh Press 
Fenyo, Mario D.. "Ferdinandy, György. 2016. Fekete karácsony ('Black Christmas'). Budapest: Fókusz Egyesület/Magyar Napló Kiadó. 203 pp. Photos." Hungarian Cultural Studies. e-Journal of the American Hungarian Educators Association, Volume 10 (2017): http://ahea.pitt.edu DOI: 10.5195/ahea.2017.288

historian by profession or, as I usually describe myself, I am a student of history. I did find what I accept as convincing information, unlike most of the often hagiographic treatments found in histories of the revolution of 1956. Part of my knowledge of the 1956 events comes from László Eörsi's excellent, critical — even if controversial — book entitled The Hungarian Revolution of 1956 - Myths and Realities, translated and absorbed by myself (New Jersey: Center for Hungarian Studies and Publications, CHSP, 2006; Budapest: Noran Könyvkiadó, 2003); as well as from pertinent chapters of the somewhat less controversial memoirs of Béla Király, Wars, Revolutions and Regime Changes in Hungary 1912-2004 - Reminiscences of an Eye-Witness (New York: Columbia University Press, 2005). Incidentally, these works were not supported by the same organization that sponsored the work of Ferdinandy. Yet, my perspective, my insights, based partly on information from those sources, are not that different from those of this author. To be sure, while I am a student of history, Ferdinandy is a man of letters. While I write mostly in English, Ferdinandy writes in several languages, including French and Spanish, but not including English, although his favorite language for writing seems to have remained Hungarian.

Ferdinandy's recollections, whether they are authentically autobiographical or fictional fragments, can also be read as a social and historical account of the 1956 events. At the end of the volume there are, as said, three photographs of the author, by an unidentified "River," taken around 1956. I can tell the photos are real. His looks have not changed that much: he is as handsome today, sixty years later, as he was then, in the uniform of a bus driver or conductor. Of course, many of us are familiar with the historical events of 1956. For instance, we know by now that Radio Free Europe and other Western media of the time encouraged the sacrifices assumed by Hungarian freedom fighters while suggesting that Western military aid was imminent, on the way. This important and tragic detail is mentioned on page 62 of Ferdinandy's book. Ferdinandy also mentions, on page 61, the fact or fiction that having fled, he delivered a speech about the Revolution in Lyons, France, to a French audience, presumably not much after his escape, since obviously the events were still fresh in the mind of his audience. That was the last time, he adds, that the world paid attention to "us" (59), meaning to the Hungarians. (Unfortunately that is also not a valid statement, since negative views and unfavorable reports about Hungary and Hungarian issues seem to continue to surface all too frequently to this day.)

On the one hand, as in other writings of Ferdinandy, it is well-nigh impossible to distinguish fact from imagination. But then again, that may well be the case of all fiction-all fiction that is worth reading - in which there are many detailed episodes that could be incorporated or woven as details into a social history, into any future account, reassessment or revision of the events. On the other hand, historical works, even social histories, tend to follow chronology. At times the stories and episodes told here appear to be in chronological order, but at other times they do not. Granted, I was not there, in 1956, hence I cannot corroborate any of the episodes, and I cannot corroborate their chronology either, other than those recorded in explicitly historical works. Does it matter? Does it matter that neither Ferdinandy nor I qualify as eyewitness observers? Yes, I would love to know whether he really lived on three continents; actually, likely factual, was married three times, and has four children, as indicated on p. 91. Is all this not both credible and true?

The Russians are not perceived as the heroes in Ferdinandy's fiction, if it is indeed fiction, because the story is written from a Western point of view. In this piece of fiction, however, the Russians are protagonists, historical or not, as real human beings in flesh rather than as the embodiment of evil-except for Stalin, who is depicted as the ultimate hóhér 
Fenyo, Mario D.. "Ferdinandy, György. 2016. Fekete karácsony ('Black Christmas'). Budapest: Fókusz Egyesület/Magyar Napló Kiadó. 203 pp. Photos." Hungarian Cultural Studies. e-Journal of the American Hungarian Educators Association, Volume 10 (2017): http://ahea.pitt.edu DOI: 10.5195/ahea.2017.288

['executioner'], who, however, cannot be held to be directly responsible for the Soviet intervention, since he died three years earlier. In sum, this book is an important work by an important contemporary writer, well worth the time invested in the reading, given the reasons indicated above, but also for its social and psychological insights, as well as for its sense of humor. I fear, however, that these qualities might not come across in an English translation. 